\title{
On becoming a cancer biologist
}

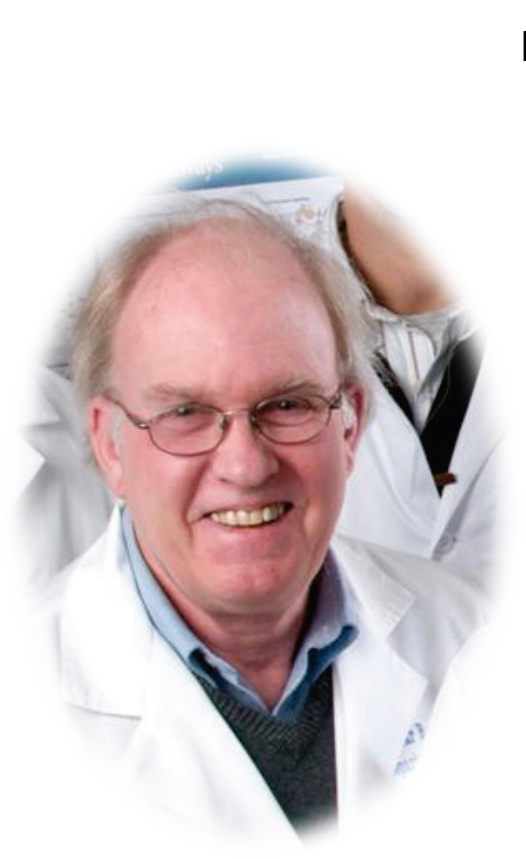

Dr. Devor is a Research Assistant Professor in the Department of Obstetrics and Gynecology at the University of lowa Carver College of Medicine

I am not a cancer biologist but I am becoming one. Becoming is a process, a transformation. Taking what was and using it as the foundation for what is or what will be. Pieces are added, others are modified. The rusty steel girders at the center of a 9-11 Memorial were once the internal supporting structure of a building. Transported and transformed, these girders become something new, surrounded by quiet walkways and marble slabs. Yet, at the same time they remain what they were- pieces of steel. The process of becoming is one of redirecting, changing context and substituting new purpose but the foundation does not change.

I am, at my core, a biologist. More than that, I am an evolutionary biologist. My view of the world is absolutely shaped by that. I see everything as the product of what Loren Eiseley called "the immense journey." Every phenomenon is the local end-point of a trail that began three and a half billion years ago when life first appeared on this planet. It is this perspective that shapes every thought and colors every interpretation.

Cells have been engaged in three and a half billion years of research and development. They have tried out countless variations. Some have been retained, most discarded. But those that have been retained have been endlessly modified, built upon, and interconnected. Redundancies and back-up systems have been installed, all supervised by the filter of survival and adaptation. Life, once it gets started, is

${ }^{1}$ The Department of Obstetrics and Gynecology, Roy J. and Lucille A. Carver College of Medicine, The University of lowa, lowa City, Iowa, USA.

Please cite this paper as: Devor EJ. On becoming a cancer biologist. Proc Obstet Gynecol. 2013;3(3 Suppl):Article 4 [ 2 p.]. Available from: http://ir.uiowa.edu/pog/. Free full text article.

Corresponding author: Eric J. Devor, Department of Obstetrics and Gynecology, University of lowa, 3234 MERF, lowa City, IA 42242. eric-devor@uiowa.edu

This is an Open Access article distributed under the terms of the Creative Commons Attribution 3.0 Unported License (http://creativecommons.org/licenses/by/3.0), which permits unrestricted use, distribution, and reproduction in any medium, provided the original work is properly cited. 
tenacious. It has been found in the most unlikely places imaginable, in the oceans at dark, crushing depths, inside rocks buried deep within the Earth's crust that are not only their home but their food source as well, and in pools of water so hot or so toxic that we dare not even touch it.

So it comes as no surprise to me that cancer cells are the formidable adversaries that they are. They, too, are the local end-point of a trail of survival and adaptation. But this trail leads in a different direction, into a shadowland where the landmarks are at once familiar and foreign. The cells traveling this road use all of the mechanisms that normal cells have so tortuously put in place over evolutionary time but to their own insidious ends. In essence, the cancer cell takes all the rules, then coopts and re-writes them. Sid Mukherjee correctly regards cancer as a parallel species, a mirror image of ourselves. And nowhere is this more clearly seen than at the molecular level in which genes shaped over billions of years to regulate and moderate cellular growth are altered by mutation and co-opted in cancer cells to promote unbridled cellular division. Genes that have been trained to respond to specific internal signals and politely usher the cell toward death are now oblivious to those signals imbuing cancer cells with an unnatural eternal life. Even more sinister perhaps is the ability of cancer cells to escape all but the most heroic attempts to kill them from without by employing the very same redundancies and back-up systems through which life itself has adapted and survived in even the harshest and most alien of environments. Thus, as Mukherjee asserts, cancer is an organism "perhaps more adapted to survival than even we are."

It is here that I now come, to try and understand these cells, this parallel species. I have, however, a powerful ally, and that ally is the perspective of an evolutionary biologist. No process exists in a vacuum, no phenomenon without context. My steel girders are evolutionary biology, transported to a new location, placed in a new milieu and re-purposed. Thus, cancer is mysterious but not a mystery, a different species but not completely alien, re-writing existing, understandable rules but not creating new ones from whole cloth. It is because of this that we have a chance, we might just win. 